\title{
The Contribution of Mary-Anne Elizabeth Plaatjies- Van Huffel to the Writing of Church Historiography in South Africa
}

Nathan Philander

Stellenbosch University

nphil@sun.ac.za

\begin{abstract}
Mary-Anne Elizabeth Plaatjies-Van Huffel introduced a fresh method of historical research that enables analysis from specific perspectives. She contended that church historians should pursue not only the meaning of authors' observable written intentions, but rather, when reading texts, distinguish between what is written and what is not written. In this way, the reading of the text provides a coherent structure. Hence, church historians should think from the framework of the decentralisation of the subject and should consequently reject the idea of a self-governing subject. She refined some of Foucault's ideas, applied them to our context and established a framework for historical research by church historians. When this is applied to church history, the emphasis should fall on power as knowledge, as it is traditionally transferred in writing.
\end{abstract}

Keywords: historiography; effective history; ecclesiastical space; historical research; church historians; Foucault; poststructuralist

\section{UNISA $\cong$}

Studia Historiae Ecclesiasticae https://upjournals.co.za/index.php/SHE/index Volume 47 | Number 2 | $2021 \mid$ |\#8170| 13 pages https://doi.org/10.25159/2412-4265/8170 ISSN 2412-4265(Online)ISSN 1017-0499(Print)

(C) The Author(s) 2021 


\section{Introduction}

This article will honour the legacy and contribution of Mary-Anne Elizabeth PlaatjiesVan Huffel (which of course is the intention of such a special edition). She introduced a fresh method of historical research, thereby offering an opportunity to do research through a specific lens. She refined Foucault's $(1970 ; 1972 ; 1976)$ model and applied it to the context of the Uniting Reformed Church in Southern Africa (URCSA), establishing a framework for historical research as a church historian. In his article: "The Life and Times of Professor Mary-Anne Plaatjies-Van Huffel: A Transformative Church Leader in Sub-Saharan Africa," Flaendorp (2014) notes that: "When Professor Plaatjies-Van Huffel was appointed lecturer in church history and church polity in 2010, she started publishing in accredited journals and made important research inputs. She quickly progressed from lecturer to senior lecturer, to head of the discipline group and to co-professor - all within four years of being at the University of Stellenbosch. This is an illustration of her sharp intellect and general giftedness. She is a lecturer par excellence and is held in high esteem by her fellow lecturers and students" (Flaendorp 2014, 60).

She made major academic contributions to URCSA and the Dutch Reformed Church (DRC) Theological Seminary in the Faculty of Theology. The DRC and URCSA jointly created a new model for spiritual formation at the Faculty of Theology in 2012, using Plaatjies-Van Huffel's design of the programme (practical training) for theological formation at the seminary. This was approved by the General Synod of the Uniting Reformed Church in Southern Africa in 2012 and is now in full operation. She proved to be a strong voice on issues of transformation at the faculty and at the University of Stellenbosch in general, focusing on contextual issues in the South African discourse at conferences and other public platforms; a main point of interest for her was the importance of using hermeneutical keys to understand church judicial matters relating to church unification, especially regarding the unification of the DRC and URCSAindeed, her contributions far exceed the confines of the University of Stellenbosch.

She regarded this issue as her biggest challenge as theologian and church leader, firmly believing that this is a biblical command, and in a recent publication on the church struggle for justice, she addressed this very issue. As co-editor of this publication, she dedicated it to "students of theology born after 1990 who have to do theology in a faithful and creative way in the aftermath of apartheid." This paper explores PlaatjiesVan Huffel's contributions to the field and discipline of church historical studies. Thus, the aim of the paper is not to determine or posit an argument about the veracity of her historical data or insights, but rather to reflect on her contributions and the extent of their relevance to our growing church, with a view to establishing and maintaining the continuous investment in this discipline.

This reflection will use a rear-view mirror approach that will enable us to look back clearly at the intended purpose of her work, in order to direct the church and church education towards a practice that promotes growth and church unification. For this 
reason, a few insights from those who influenced her will be investigated, like Foucault (1972), for example. Again, this paper does not seek to explore how accurate her interpretation of various scholars is, but rather to explore these historical insights from a unique perspective. The goal is clear: namely to pave the way for an open discussion of church history, not as something to not be seen in hindsight, but as something that we carry with us as we strive to open and unfold new possibilities for a uniformed church.

\section{Church Historiography Demands Investigation of the Underlying Discourses in the Text}

Plaatjies-Van Huffel $(2012,78)$ notes that when it is concerned with church history, the emphasis should rather be on power than on knowledge as it is conveyed in traditional historiography. Church historians should take note that people are influenced by social discourses and/or social formations (Plaatjies-Van Huffel 2012, 78). Hence, church historiography demands investigation of the underlying discourses in the text and/or reality (Plaatjies-Van Huffel 2012, 79).

Plaatjies-Van Huffel $(2012,79)$ notes that Foucault's poststructuralist approach is in fact opposed to structuralism. She contends that Foucault agrees with neither the manner in which structuralism thinks about structures, nor with the characteristics of the new philosophical position of post-structuralism (Plaatjies-Van Huffel 2012, 79). Hence, and/or reality is established (Plaatjies-Van Huffel 2012, 79). She is of the opinion that Michel Foucault was never truly a structuralist in the strictest sense of the word and that he explicitly distinguishes himself from atomistic structuralism and later even distances himself from it. She notes that Foucault's poststructuralist approach is in fact opposed to structuralism (Plaatjies-Van Huffel 2012, 79).

According to her, it is evident that Foucault does not agree with the characteristics of the new philosophical position of post-structuralism (Plaatjies-Van Huffel 2012, 79) post-structuralism is mainly concerned with the question of institutional control and power. Plaatjies-Van Huffel $(2012$, 80) further notes that Foucault is generally considered a non-historical historian, an anti-structuralistic structuralist and a humanistic scientist, someone who considers events critically. His main thesis is that history is to a large extent an illusion.

Foucault (1972) juxtaposes effective history to traditional history, which refers to the search for sources, the determination of continuity, the finding of similarities and the tabling of development with some goal in mind (Plaatjies-Van Huffel 2012, 80). Effective history refers to the tabling of breaks and discontinuities that disrupt the unity of the subject and breaks the search for the origin and end goal (Plaatjies-Van Huffel 2012, 80).

She opposes the traditional development model of history: Foucault criticises the traditional scheme of historical inquiry. She also notes that according to Foucault, the 
instruments that enable historians to make analyses are partially inherited and partially their own analyses (Plaatjies-Van Huffel 2012, 81). She remarks that according to Foucault, history in its traditional form is aimed at memorising the monuments of the past, transforming them into documents and giving voice to these signs, which are often in themselves not verbal. In the same vein he rejects the teleological view of scientific history which focuses on the discovery of knowledge of the past that is still important for people today. Plaatjies-Van Huffel $(2012,81)$ believes that the South African church historians, for example, emphasise the continuity in history while Foucault points out and emphasises the discontinuities, the interruptions in the story line. She suggests that today's church historians should not strive to write the history of the past in terms of the present, but should rather see history as a social construct. According to Adonis:

Church Historiography, and the reinterpretation of South African Church History, is a subject, which in the recent past had been debated, by colleagues and historians on various occasions. Aspects such as the relationship between church and general history and the various tendencies in Church Historiography are some of the most important issues, which are up for discussion. Another important aspect in South African Church History in particular, is the perspective from which church history had been described during the past decades. Special thought has been given to the presuppositions of scientists in this academic activity. The appeal that is being made in this regard is that South African Church Historiography should not be seen and practiced as separate histories of various denominations, but as a unit, which is being described from various perspectives. (Adonis 2002, 7)

Furthermore, in his article, "Remembering the Role of the Reformed Churches in the Struggle for Justice in South Africa: Some Remarks on Promise and Pitfalls of Memory and Historiography," Vosloo (2013) further categorically states that the presentation of the past may not be accompanied by generalisations or stereotypes that are sometimes the result of ignorance or irresponsible handling of sources (Vosloo 2013, 21). The emphasis should be on investigating primary sources and continuing to do archival research, since the quality of research of church history depends largely on documents preserved for the purpose (Vosloo 2013, 21). While the use of primary resources is as important as the ways in which a historian might diverge from them, care should be taken to avoid historical offers without presentation (Vosloo 2013, 21).

This means that, in our involvement with our Reformed past, we must not separate the emphasis and importance of our primary sources from hermeneutical concerns (Vosloo 2013, 21). This is precisely one of the critical points against our Reformed historiography in the past-the shortage of the necessary hermeneutical understanding and/or understanding (sensibility) (Vosloo 2013, 21). The nature of this topic, as it pertains to the Reformed Churches in South Africa, has come to be seen as problematic. Some historians warn against degeneration due to the observance of too narrow a geographical boundary when discussing historical events (Vosloo 2013, 21). 
Vosloo $(2013,22)$ is of the opinion that something like a Reformed Church in South Africa does not actually exist, but that it is part of a larger whole, each with its own historical legacy, its own social context, practices and its own dominant language: "Our history has in many cases been weaved with one another," according to Vosloo. He clearly states, among other things, that an understanding of the importance of memory and history requires us to not think in isolation of our past and history: This suggests that we can understand our own complex histories better in conversation with others and through an openness to each other's histories (Vosloo,2013, 22). Moreover, we should also remember in the process that we are ourselves "othered" in the histories of others (Vosloo 2013, 22). An understanding of the interwovenness of our memories and histories, therefore, requires that we resist the temptation to think in isolation about what we regard as our past and our history (Vosloo 2013, 22).

Plaatjies-Van Huffel $(2012,81)$ is of the opinion that archaeological historiography can be used to shed light on the underlying discourses in different church historical periods, while Foucault uses the term "archaeology" to refer to the discursive formation of various societies, with the goal of shedding light on the events that produced the knowledge field and discursive formation in different periods. Plaatjies-Van Huffel $(2012,81)$ notes that Foucault (1972) strives to determine the ordinary history, particularly the background against which certain changes in medical language evolved. Plaatjies-Van Huffel believes that church historians should strive to determine the background to the changes in the usage of terms in church historic sources (PlaatjiesVan Huffel 2012, 82). She also believes that church historians should rather investigate the underlying discourse in the text and/or reality-she posits that church historians should reconsider the ready-made synthesis that is normally accepted without investigation or question (Plaatjies-Van Huffel 2012, 82).

Ricoeur, on the other hand, describes archaeology as follows: "It is nothing more than a rewriting: that is, in the preserved form of exteriority, a regulated transformation of what has already been written" (Ricoeur cited in Plaatjies-Van Huffel 2012, 83). Plaatjies-Van Huffel $(2012,83)$ continues to say: "Thus, the purpose of archaeology, according to Ricoeur, is not to prevent differences, but rather to make a difference in the goal of the analysis, to explain precisely what it is, to distinguish it." She describes the difference between archive and archaeology as follows: "Archive is the register of discursive formation while archaeology is the description of the inter-discursive transformation and maintains that the genealogical historiography can also be used fruitfully by church historians" (Plaatjies-Van Huffel 2012, 83).

She notes that Foucault (1970) defines "genealogical" as a form of history that considers the constitution of knowledge, and and/or discourses without referring to the subject. Furthermore, she suggests that the most visible difference between genealogy and archaeology is that genealogy puts the emphasis on power, and not on knowledge, as is the case with archaeological historiography (Plaatjies-Van Huffel 2012, 83). According to Plaatjies-Van Huffel, the genealogist is a diagnostician who focuses on the 
relationships of power, knowledge, and the body in modern society. Genealogy searches for discontinuities where others find continuities. She contends that in genealogical historiography, the historians avoid the search for deep structures, but rather place emphasis on the superficial meaning of events, smaller details, small shifts, and that subtly genealogically speaking, the depth structures of a text are only accessible when the genealogist observes things from a distance.

Plaatjies-Van Huffel $(2012,84)$ concludes that church historians should, therefore, consciously deal with it, and that according to Foucault there is primarily nothing to interpret, as everything has already been interpreted. Plaatjies-Van Huffel $(2012,84)$ further notes that the focus in church history writing should also fall on the cultural practices that constituted the people as objects of the discourse.

\section{Church Historians should Analyse the Dominant Discourses in Church History}

Plaatjies-Van Huffel $(2012,84)$ believes that church historians should analyse the dominant discourses in church history, considering that discourses are products of social factors, power, and practices, rather than an individual set of views. Plaatjies-Van Huffel $(2012,84)$ notes that according to Foucault $(1970)$, discourses can be understood as a series of events and refer to interdependent systems of statements that are related to general meanings and values. Plaatjies-Van Huffel $(2012,84)$ points out that the discourses are also multiple and provide a multitude of ways to give meaning to the world. Plaatjies-Van Huffel $(2012,84)$ believes that the church-historical texts are approached in discourse analysis in their own right, and not as a secondary route to that beyond the text, such as attitudes, events and/or cognitive processes.

In his article: "Quo Vadis Church History? Some Theses on the Future of Church History as an Academic Theological Discipline," Vosloo (2009, 54-64) comments on whether the teaching of church history, as an academic theological discipline, has any future at all. "Is there any validity to church history as an academic theological discipline?" To ask that question is important. The question can also be asked whether it cannot just become part of the general teaching of history at the Faculty of Humanities. Why bother with church history as an academic theological discipline? The question is: Can church history, from the past, make any contribution to the present and the future, in terms of nation building? Can we talk about a shared church history, if we are sitting with a divided church family, in this case the Dutch Reformed Church family?

If there is talk of a contribution to the present and the future, have the contributions of the people of colour been recognised, in terms of the teaching of church history? You cannot side-step this question. It cannot be handled unilaterally. In the discordant history of the Dutch Reformed Church family, the divisions run parallel to each other and are not intertwined at all. In response to the topic, Vosloo (2009, 55-63) mentions five theses, namely: "The vitality of church history as an academic discipline is linked to its 
ability to contribute towards a responsible engagement with the Christian past in a culture of historical amnesia and harmful memory" (Vosloo 2009, 55-57). Historical amnesia is dangerous. Some memory of the past caused harm and church history can correct that. The loss of memory made the church unhealthy. We need to know where we are coming from, what went wrong along the way, where we stand now, if we have any hope for future outcomes. Church history can only act responsibly if it treats those memories of the past as having equal importance.

With this in mind, we need to know that our insight regarding the future influences our understanding of church history. Only then can one rise from the ashes. To be able to do that, we need people with a stronger historical, sympathetic and critical awareness in our search for the whole story. As opposed to this, according to Plaatjies-Van Huffel $(2012$, 85), Foucault is of the opinion that knowledge, ideas, presentations, images and/or themes always present the discourse in a localised sense. Thus, there is no method for performing discourse analysis.

She notes that Foucault treats everything that is said in the human sciences as discourses. Plaatjies-Van Huffel $(2012,85)$ notes that consequently, all forms of discourses are approached with suspicion and church historians should, therefore, move away from the assumption that all meaning and knowledge are constituted by language. Plaatjies-Van Huffel $(2012,85)$ further notes that church historians should also be aware that all knowledge is socially constituted and they should, therefore, approach historical documents critically. She believes that church historians should be aware that objects (just like humans) are constituted by social discourses and/or social formations (Plaatjies-Van Huffel 2012, 85). She notes that Foucault (1976) studies the dominant discourses and their relative dependence on social structures and shows, among other things, how insanity and sexuality were constituted by social discourses and/or social formations (Plaatjies-Van Huffel 2012, 86).

Plaatjies-Van Huffel $(2012,86)$ notes that in Foucault's footsteps, church historians should, therefore, not only systematise events in a chronological manner but should also describe the authorities of limitation. She is further of the opinion that church historians should also describe the institutional terrain that underpins the discourse, and ensure that it is accepted as a legitimate source and point of application. She suggests that church historians could well succeed in conveying the juxtaposition of continuity and discontinuity, power and discourse as parallel pairs in a striking way in church history, and in making connections about how the church historians played a role in the constitution of objects. Plaatjies-Van Huffel $(2012,87)$ states pertinently that church historians should assume that a text also develops its own history of interpretation, which necessitates further reading and re-reading of the text. She further mentions that church historians should take note of the fact that a form of social power is also embedded in the criteria according to which different interpretations of a text are assessed to determine which interpretation of a text is correct or better (Plaatjies-Van Huffel 2012, 87). 
She notes that Foucault, in turn, regards knowledge and power as synonymous (Plaatjies-Van Huffel 2012, 87). She believes that the task of church historians is to reveal the power-knowledge relation. Furthermore, with the rise of historical philology, language becomes subject to deep structures of which the language user is not even directly aware, because the autonomy of the text is naturally assumed (Plaatjies-Van Huffel 2012, 88). According to her, church historical texts should be read taking into consideration what has been written, as well as what has not been written. She notes that such a reading of the text makes a coherent structure more clearly observable. Furthermore, she contends that traditional criticism deals with the question of the author's intention, while poststructuralism differs from this.

In his article "Kerkgeskiedskrywing in Suid-Afrika: 'n Kritiese Evaluering," Adonis asks the question: What is meant by the methodology of church writing? Adonis (2002, 16-17) explains it as follows: "In the method of church history, usually a theoretical division is included in which the formal aspects of church historical research come to the order." The acquisition of resources contradicts an important part of this. In addition, there is a section dealing with the philosophies that are covered, based on the preacquisitions of the investigator (Adonis 2002, 16). A third section forms the practical part, showing how church history adopts different forms from different investigators (Adonis 2002, 16). Regarding the inclusion of the church historical literature, in which the histories of churches, missionary societies or other church or Christian religious institutions, two comments may be made on this (Adonis 2002, 17):

(1) It seems that most of this type of history (especially those that go across the histories of churches) has been done in a way that has strongly emphasised the institutional character of church life (Adonis 2002, 17). According to this, the institutions of church life, the choice of leadership figures (especially the missionaries), highlighted the importance and authority of church meetings, church buildings, schools and hospitals, etc. (Adonis 2002, 17). Little attention has been given to the life of the people in general, nor to the social, political and economic context in which they lived. Also, the meaning of their culture did not receive the necessary attention (Adonis 2002, 17).

(2) In this history, locals were viewed in terms of Western ideas, so that Western written sources are strongly emphasised at the expense of oral resources (Adonis 2002, 17). In certain cases, the oral sources are sometimes distorted or even silenced. In addition, the locals are seen as objects and not as subjects of their own history (Adonis 2002, 17). Furthermore, their contribution to the establishment and building up of the church was also disregarded (Adonis 2002, 17). Most historians, including church historians, therefore delivered biased work, largely based on written documents, and displaying the ideas and perceptions of the ruling masters (Adonis 2002, 17). The resistance of indigenous Christians, although in some cases it could not be openly observed, was not taken seriously (Adonis 2002, 17). When the moments of public resistance were observed, as in the segregation of indigenous Christians and 
Western oriented church-goers, they were supported by all kinds of wrong motivations (Adonis 2002, 17).

In a poststructuralist approach, the interpretation is indicated by the text; not so much by the author (Plaatjies-Van Huffel 2012, 88). She notes that the author, as well as the reader and his/her intentions, is no longer determining factors in understanding the text. Rather, the meaning is determined by an ongoing and inter-subjectivist process (Plaatjies-Van Huffel 2012, 88). She notes that in addition, structuralist hermeneutics seeks to understand the text independently of the author, attempting to understand the author's intentions better than the author. Although there is no absolute understanding of the text, we must in the reading process pay attention to those who are criticised, as well as those who are rejected or excluded, according to Foucault (Plaatjies-Van Huffel 2012, 88).

Plaatjies-Van Huffel $(2012,88)$ believes that church historians should, therefore, not only ask what the intentions of the author are, but should rather, when reading texts, distinguish between what is written and what is not written. In this way, the reading of the text provides a coherent structure. Hence, church historians should think from within the framework of the decentralisation of the subject and should consequently reject the idea of a self-governing subject (Plaatjies-van Huffel 2012, 88). She believes that church historians should take into account the fact that few or no universal truths can be found in a post-structuralist model (Plaatjies-Van Huffel 2012, 89). Even objective truth is unattainable in the mentioned model, and there is also no room for the constitution of the truth by means of the subject (Plaatjies-Van Huffel 2012, 89). She notes here that Foucault himself rejects the notion of truth as well as the traditional belief in scientific processes. Plaatjies-Van Huffel $(2012,89)$ posits that, according to Foucault, the truth is a function of social status, and political by nature, rather than being based on facts. In the post-structuralist approach, knowledge is considered non-neutral and is associated with empowerment, while Foucault refuses to accept knowledge as objective and rather regards it as an instrument of social manipulation (Plaatjies-Van Huffel 2012, 89).

She notes that Foucault believes that knowledge is not morally neutral and emphasises the ordering of things, which allows one to express certain things while rendering other issues unthinkable. Plaatjies-Van Huffel $(2019,89)$ shows that Foucault prefers to focus on the marginalised aspect of social existence that has sometimes been completely ignored by philosophers, especially with reference to prisons, psychiatric institutions, institutions for lepers, and so on (Plaatjies-Van Huffel 2012, 89). On the other hand, she makes it clear that church historians cannot achieve objective historiography and that they need to guard against mindlessly repeating universal truisms. Church history should, therefore, be socially constituted. Church historical sources are often nonneutral and associated with power. It is, therefore, impossible for church historians to analyse church historical sources in an objective way (Plaatjies-Van Huffel 2012, 89).

Hence, church historians should analyse the historical relationship between truth, knowledge, and power and more emphasis should be placed on exposing the underlying 
discourses of power (Plaatjies-Van Huffel 2012, 90). Plaatjies-Van Huffel further indicates here that the all-encompassing control and/or discipline in society is maintained through the legal system and that it applies to all communities. PlaatjiesVan Huffel $(2012,91)$ notes that Foucault shows how, by means of a Panopticon structure, individuals could be continuously monitored, controlled and disciplined. In the mentioned structure, residents are constantly placed under supervision and monitored, but its success lies in the fact that supervision can be permanent, thorough, and ubiquitous (Plaatjies-Van Huffel 2012, 91). The Panopticon is an archetype of the new technologies of power and can be used as a tool to change behaviour, to train and/or rehabilitate individuals and to exercise power spatially (Plaatjies-Van Huffel 2012, 91). She notes that Foucault gives a radically new interpretation of both power and knowledge. He does not see power as a possession that one group has and that the other group lacks.

She believes that church historians should, therefore, focus on isolating, identifying, and analysing the web of unequal relations in history (Plaatjies-Van Huffel 2012, 91). However, the main purpose in church history writing should not be to attack a certain institution of power, the government, a certain group, church and/or class, but should much rather emphasise that power is woven into all social relations (Plaatjies-Van Huffel 2012, 92). She further believes that Foucault's historiographical approach can be used as a lens for historical investigations. There should be a shift from traditional historiography to general historiography (Plaatjies-Van Huffel 2012, 92).

In her opinion, church historians should, therefore, emphasise the discontinuities and should point out the interruptions in the story line (Plaatjies-Van Huffel 2012, 94). They should attempt to ascertain the background of the changes that took place during the historical periods. They should also move away from the presupposition that all meaning and knowledge are constituted by language (Plaatjies-Van Huffel 2012, 94). She further believes that church historians should also describe the institutional areas from which the discursive contributions can be made (Plaatjies-Van Huffel 2012, 94). Church historians should be aware that people are constituted by social discourses and/or social formations. Consequently, the underlying discourses in the text and/or reality should be examined in historiography. Historiography will always be with us, but how we understand what we read (hermeneutics), and the premise from which everything is told, also determine the value of the content of the narrative, beyond the personal background and circumstances of the individual's memory.

\section{Conclusion}

If research on historiography is only concerned with sources stored in archives, with books and articles that have been well researched, and with libraries that sometimes lack sources on certain topics, then I believe we make a mistake if we fail to take into account the real stories that took place and are told and retold in our communities. Then we might become academically poorer and remain poor instead of being enriched by the contribution of personal memory/memories and identities - however flawed and full of 
mistakes they may be. I believe that one never relies on historiography as pure and without negative input or untruths, because that is how we as a society have been informed and educated about the past over the centuries, no matter how flawed, untrue, uncertain, irrelevant and incomprehensible the narratives have been.

History, yes, all history has gaps, but that does not mean that there is no value in the narratives from which we can learn. The people who relate them have their own context, background (social or political) and shortcomings. They may have been hurt in the process; they may still carry the wounds of their memories. Can we ever rely on historiography being pure and without negative input or untruths? No. Church historians should, therefore, base their thinking on the framework of the decentralisation of the subject and should consequently reject the notion of a self-governing subject. This assumes that the task of the church historian involves, among other things, showing how the power relations of inequality and oppression are created by social practices. Church historians, according to Plaatjies-Van Huffel, benefit from considering the framework of decentralisation of the subject and consequently being able to reject the idea of a selfgoverning subject.

Plaatjies-Van Huffel (2012) suggests the following regarding the historiography:

(i) She contends that church historians should explore the underlying discourse in the text. Plaatjies-Van Huffel $(2012,82)$ advocated careful examination of subconsciously made rules that determined specific philosophies and ideologies, such as those established during a specific era, for example during the times of apartheid and colonial rule. Plaatjies-Van Huffel contends that, when church historians accept pre-existing generally accepted syntheses without examining their validity, the pre-existential forms of continuity as well as the well-worn categories of the past, should be queried (Plaatjies-Van Huffel 2012, 82).

(ii) Plaatjies-Van Huffel $(2012,84)$ maintains that church historians should analyse the dominant discourses in church history, taking into account the fact that these discourses are products of social issues, power and practices rather than an individual set of ideas. According to her, the analysis of discourse entails, amongst others, a careful reading of texts with a view to revealing discursive patterns of meaning, contradictions and/or inconsistencies.

(iii) Church historians should, therefore, take as point of departure that all meaning and knowledge are created by language (Plaatjies-Van Huffel 2012, 85). Any interpretation or understanding of an object or of occurrences is, therefore, determined by a specific discourse, e.g., historiography pertaining to the colonial era, apartheid and post-apartheid, will necessarily present different viewpoints of events (Plaatjies-Van Huffel 2012, 85).

(iv) Plaatjies-Van Huffel maintains that church historians should, therefore, according to Foucault, avoid merely systematising events chronologically, and 
also question the authority of the set parameters (Plaatjies-Van Huffel 2012, 87). Church historians should describe the institutional terrain that informs the discourse and provides it with legitimacy as source and method of application (Plaatjies-Van Huffel 2012, 87). In keeping with Foucault's approach, the following points provide a guideline for church historians' exploration of historical events.

a. Who is the speaker?

b. What is the status of the person who is entitled to speak?

c. Who, within the total group of voices, has been entitled to use this specific language register?

d. Who is qualified to speak, and why?

e. Has the right to speak been sanctioned by law or tradition?

f. Who is juridically or spontaneously acceptable as presenter of this discourse? Is the power juridically defined, or is it spontaneously acknowledged?

g. Which institutional spaces and/or podia are available that will allow a person to contribute to the discourse?

h. What is the position of the subject?

i. How does the subject stand in relation to different objects? How are various groupings interrelated?

\section{References}

Adonis, J. C. 2002. "Kerkgeskiedskrywing in Suider-Afrika: 'n Kritiese Evaluering.” NGTT 43 $(1 \& 2)$.

Flaendorp, C. 2014. "The Life and Times of Professor Mary-Anne Plaatjies-Van Huffel: A Transformative Church Leader in Sub-Saharan Africa." Studia Historiae Ecclesiasticae 40 (Supplement): 53-66.

Foucault, M. 1970. Order of Things: An Archaeology of Human Science, translated by Sheridan Smith. New York: Vintage Books.

Foucault, M. 1972. The Birth of a Clinic: An Archaeology of Medical Perception, translated by A.M. Sheridan Smith. New York: Tavistock.

Foucault, M. 1976. History of Sexuality, Vol 1. An Introduction, translated by Hurley in 1978. New York: Vintage Books.

Plaatjies-Van Huffel, Mary-Anne E. 2012. "Michel Foucault se Historiese Benadering as Lens in Historiese Ondersoeke." Acta Theologica 32 (1): 78-95.

https://doi.org/10.4314/actat.v32i1.5. 


\section{Philander}

Vosloo, R. 2009. "Quo Vadis Church History? Some Theses on the Future of Church History as an Academic Theological Discipline.” Scriptura 100: 54-64.

https://doi.org/10.7833/100-0-653.

Vosloo, R. 2013. "Remembering the Role of the Reformed Churches in the Struggle for Justice in South Africa: Some Remarks on Promise and Pitfalls of Memory and Historiography." NGTT 54 (3\&4) (September \& December 1960-1990): 1-10. https://doi.org/10.5952/543-4-395. 